\title{
EDUCATIONAL SERVICES IN THE SUBURBAN ZONE OF SZCZECIN (POLAND)
}

\section{TOMASZ RYDZEWSKI}

University of Szczecin, Faculty of Geosciences, POLAND

e-mail: tomasz.rydzewski@usz.edu.pl

\author{
\begin{tabular}{l|l} 
RECEIVED & 10 December 2018
\end{tabular} \\ ACCEPTED 28 December 2018 \\ JEL \\ CLASSIFICATION \\ $H 75$, I21, R53
}

KEYWORDS services, educational services, suburban zone, Szczecin

ABSTRACT The main objective of the study was to analyze the diversification of the potential of educational services of communes (NUTS 5) belonging to the suburban area of Szczecin, at all levels of general education (International Standard Classification of Education, ISCED 1, 2 and 3) in the 2016/2017 school year - primary, junior high school, and high schools. The research covered 19 communes forming the internal and external ring surrounding Szczecin. For this purpose, following measures of the potential of educational services were used: the number of schools, school classes, pupils and teachers' posts, as well as educational indicators, i.e. the number of pupils per school, the number of classes per school, and the number of full-time teacher's position per school. In order to determine the demand for educational services, a gross enrollment rate was applied to individual communes. The final result of the research is a synthetic map of the potential of educational services for the communes of the suburban zone of Szczecin.

\section{Introduction}

The system of general education in Poland is subject of constant changes. On 1 September 1999, a school reform was introduced, which transformed the two-stage system of education into a three-stage system that had been in force since 1968. The existing 8-year primary school (ISCED 1,2) and secondary schools - high school (ISCED 3A), technical school (ISCED 3B), basic vocational school (ISCED 3C), replaced by a 6 -year primary school 
(ISCED 1), 3-year junior high school (ISCED 2) and high schools (ISCED 3A, 3B, 3C). Learning at the levels ISCED 1 and 2 was obligatory. The main assumption of the reform was to popularize and raise the level of secondary education. After graduating from middle school (ISCED 2), students could continue their education by choosing one of the upper secondary school types (ISCED 3): 3-year general high school (ISCED 3A), 4-year technical high school (ISCED 3B) 2- or 3-year school professional qualifications (ISCED 3C). Along with the reform, a system of external examinations was introduced at all levels of education. Despite the initial social opposition, from the perspective of 18 years of the duration of the reform, it can be said that in the majority it met the expectations set in it. It seems that the only serious mistake was the marginalization of vocational education (ISCED 3C). The presented analysis was carried out for ISCED level 1, 2 and 3 level schools without subdivision into subtypes A, B and C.

Starting from the 2017/2018 school year, the implementation of a new education reform has begun, which consists in gradual liquidation of junior high schools, restoration of 8-year primary schools (ISCED 1, 2), 4-year general secondary schools (ISCED 3A) and 5-year technical secondary schools (ISCED 3B), and transformation of basic vocational schools (ISCED 3C) into trade schools I (3-year) and II (2-year).

The uncontrolled development of the suburban zone of large cities (urban sprawl), including Szczecin, is a serious economic and social problem. The significant dynamics of social, economic and spatial changes in these areas is directly related to the desire to live in single-family houses with a garden or escape from the hustle and bustle and pollution of a large city. As a result, the suburban areas of Szczecin populate at a high rate (Rydzewski, 2005a, pp. 69-80; Rydzewski, 2005b, 52-60; Rydzewski, Smutek, 2016, pp. 153-165). Only in the commune of Dobra, the population in the years 2000-2017 increased almost three times (from 8620 to 22511 inhabitants), both as a result of migration from Szczecin and high birth rate.

In most of these areas, apart from areas designated for housing, they are not prepared for servicing such a dynamically developing population. This applies, among others education, which must provide places in schools for the increasing number of school-age children. Occurrence of a fairly poor educational offer in suburban areas forces many parents to bring their children to schools located in Szczecin and other communes, which causes daily shuttle migration. This leads to an increase in the intensity of individual transport, and thus larger traffic jams, deterioration of the environment, longer travel times, and consequently negatively affect family life.

\section{Area and method of research}

\section{Delimitation of the suburban zone of Szczecin}

The concept of a suburban area is not unequivocal and is defined differently, which leads to the use of various criteria in its delimitation (Marcinowicz, 2000, pp. 291-309, Rydzewski, 2005a, pp. 52-60; Rydzewski, 2005b, pp. 69-80, Konecka-Szydłowska, 2006, pp. 143-156). The number of papers on delimitation of suburban zones of big cities in Poland is also limited, which concerns in particular Szczecin. T. Rydzewski (2005a, p. 52) defines "the suburban zone is an area surrounding and showing close functional connections with the main urban center". In this study, communes bordering with Szczecin (inner ring) and communes bordering the inner ring (outer ring) were considered as suburban zone. The so designated suburban zone of Szczecin consists of: 3 urban-rural communes (Goleniów, Gryfino, Police) and 4 rural communes (Dobra, Kobylanka, Kołbaskowo, Stare Czarnowo) - inner ring and 1 urban commune (Stargard), 3 urban-rural (Maszewo, Nowe Warpno, Pyrzyce) and 8 rural communes (Banie, Bielice, Osina, Przybiernów, Stargard, Stepnica, Warnice, Widuchowa) - outer ring. In total, 19 communes were analyzed (Figure 1). 


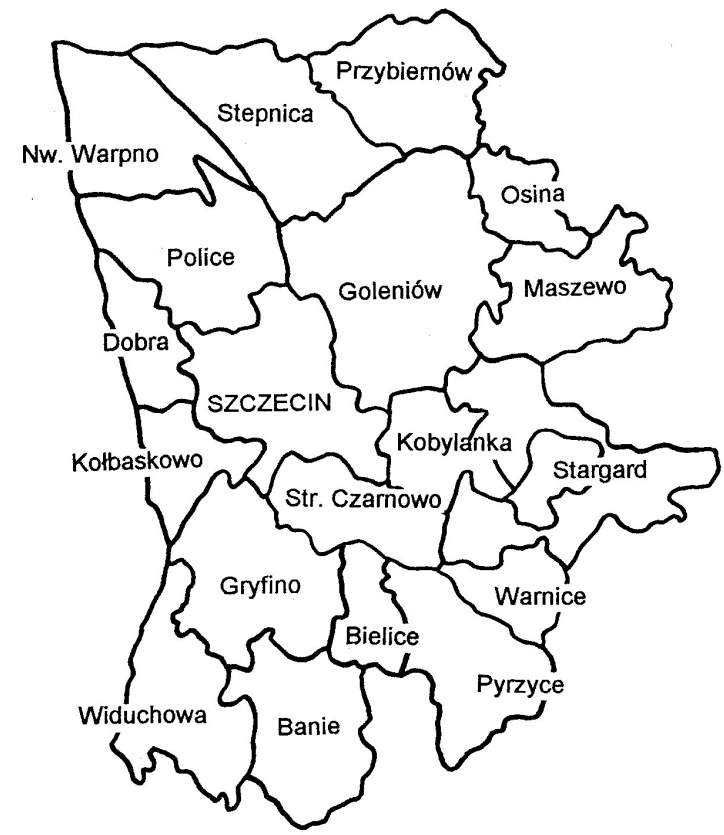

Figure 1. The communes of the suburban zone of Szczecin

Source: own study.

\section{Measure of the potential of educational services}

The study applied a measure of the number of schools, school classes, pupils and teachers' posts at ISCED levels 1, 2 and 3. The study covered the school year 2016/2017, the last before the introduction of the new education reform. The source of data was the publication of the Statistical Office in Szczecin (Województwo zachodniopomorskie..., 2017) and the Local Data Bank (2018) of the Central Statistical Office in Warsaw. For practical reasons, the number of all teachers working at particular levels of education (full-time and part-time employees) has been converted into full-time, i.e. 18 teaching hours per week.

\section{Educational indicators}

Using the abovementioned measures, selected educational indicators were calculated (Herczyński, 2012, pp. 31-37). The number of pupils was related to the number of schools, the number of classes and the number of fulltime teacher's position per school. In addition, to determine the level of satisfaction of the demand for educational services, a gross enrollment rate was calculated for individual communes, which determines the ratio of the number of all learners at a given level in a given area to the entire population of people in the age nominally assigned to this level of education living in this area. 


\section{A synthetic measure of the potential of eductitional services}

In order to evaluate the potential of educational services in the suburban area of Szczecin in the 2016/2017 school year at all levels of general education (ISCED 1, 2, 3), the obtained indicators were divided into 3 groups, giving them a point value based on their statistical differentiation (better -3 points, average -2 points, worse - 1 point). The sums of points are a synthetic measure. It was presented on the map, where four classes were distinguished: the highest, high, average and the lowest potential of educational services.

\section{Results}

\section{Primary schools (ISCED 1)}

In the area of Szczecin's suburban area, in the school year 2016/2017 there were 86 elementary schools, with 978 school classes, in which 17,899 pupils was learning. Teachers were employed in schools, for whom almost 1,300 positions were prepared. The largest number of schools were characterized by the following communes: Police (13), Goleniów (12) and Stargard (11), whose share in the suburban area was almost $42 \%$. Among rural communes, the largest number of primary schools was located in the following: Dobra, Kołbaskowo and Stargard (5 schools per each). The largest number of school classes (203), and thus also pupils $(4,137)$, occurred in the city of Stargard, which in the case of school branches accounted for over $1 / 5$ and pupils - almost $1 / 4$ of the value of these measures in the scale of the entire suburban area. Also in the case of teachers' posts, the largest number of them were characterized by the Stargard urban commune. Among rural communes, the largest values of the number of school classes and pupils as well as full-time teacher's position were characterized by the following: Dobra and Kołbaskowo, located in the inner ring of the suburban zone of Szczecin. In both cases, such high values of these three measures are largely the result of the construction of new school facilities in Mierzyn and Przecław. The lowest rates were mainly found in schools from sparsely populated rural communes (Bielice, Osina, and Stare Czarnowo) and the commune Nowe Warpno, for whom the close proximity of Szczecin and Police is a competition.

In the school year 2017/218, in the suburban area of Szczecin, the only commune where there was less than 100 pupils per one school was Nowe Warpno, and namely 63.0. This was mainly due to the small population living in the commune area, and hence a small number of children aged 7-12. In addition, for the area of the Nowe Warpno commune, the gross enrollment ratio was one of the lowest in the zone (65.6\%), as most children use school facilities outside the commune in Police and Szczecin. In addition, the Nowe Warpno commune was characterized by the lowest value of other indicators: the number of pupils per class (12.6) and the full-time teacher's position (10.0). Statistically, the largest primary schools were located in the municipality of Stargard, where there were more than 376 pupils per one school, considering the typical urban character of the commune. Among the rural communes, the highest value of this indicator was characterized by the Dobra commune (less than 277 pupils per school). Both communes had the most numerous classes, in which the number of pupils per class exceeded 20 persons as the only ones in the analyzed area. In addition, in the commune of Dobra for one full-time teacher's position there was the largest number of pupils in the whole suburban area (16.4). Although in the Dobra commune there were as many as 5 primary schools, they were significantly overcrowded, and it must be remembered that every third child aged 7-12 was transported to school facilities, as evidenced by the very low gross enrollment rate (62.8\%). The lowest was recorded in the Stargard rural commune, in which almost $2 / 5$ of children attended primary 
schools in the city of Stargard and the nearby village commune Warnice, where the aforementioned coefficient reached the highest values, respectively $105.1 \%$ and $107.9 \%$.

\section{Junior high schools (ISCED 2)}

In the Szczecin suburban area, in the school year 2016/2017, there were 46 junior high school institutions with 380 classes, attended by 7,625 pupils. Teachers were responsible for their education, for whom less than 630 positions were prepared. Only in urban-rural communes: Police (the largest number of junior high schools -9), Goleniów, Gryfino and Pyrzyce and the Stargard urban commune, the number of junior high schools was greater than 1. In total, in all five communes there were almost $72 \%$ of all schools of this type. The only commune in which no junior high school was functioning was the Stargard rural commune. Analyzing the number of pupils, it can be seen that their largest population attended Stargard junior high schools, and the smallest to junior high schools in the following communes: Nowe Warpno (only 19 pupils) and Dobra (53 pupils). In the case of the Dobra commune, this may be a bit of a surprise, but taking into account the fact that the only municipal junior high school is located in Dołuje, which lives around $5 \%$ of the commune's population, parents prefer to bring their children to Szczecin. The largest number of junior high school full-time teacher's positions appeared in Stargard, and the smallest in the Nowe Warpno commune.

The Nowe Warpno commune, as in the case of primary education, was characterized by the lowest indicators of the potential of junior high schools. In Nowe Warpno junior high schools, only 19 pupils studied on three levels of education, which made an average of 6.3 pupils per class. In addition, there was only 4.5 pupils per one full-time teacher position. The majority of rural communes in the analyzed area were characterized by quite low values of these indicators (the exception was the Kołbaskowo commune). At the other extreme is the urban commune of Stargard, where the junior high schools with the largest number of pupils (284.6) and the largest school classes (22.5 pupils) were statistically located. The lowest comfort of work was provided by junior high school teachers in the Kobylanka commune, where there were 13-14 pupils per one full-time teacher. For the pupils, the most attractive the junior high schools were located in cities that in many cases provide a high level of education. The gross enrollment rate above $100 \%$ was held by the municipalities: Stargard (118.3\%) and urban-rural Police (104.8\%) and Pyrzyce (101.2\%). The high gross enrollment rate for junior high schools located in the Stargard rural commune is largely the result of the lack of a junior high schools school in the area of the Stargard rural commune. The proximity of Szczecin and the location of the junior high schools in Dołuje was the cause of a very low gross enrollment rate for the Dobra commune. Only a little over $6 \%$ of the population of junior high school children living in the municipalities studied at junior high school.

\section{High schools (ISCED 3)}

In the case of high schools, we are dealing with young people, usually between 16 and 18 years old, which is why in this type of school, the location of this type of school does not matter, but most of all its teaching profile and reputation is of such importance. High schools in the suburban area of Szczecin were located only in larger towns constituting the capitals of urban-rural communes, and poviats (NUTS 4), i.e. Pyrzyce, Police, Gryfino or Goleniów, and in the Stargard urban commune, a capital of poviat as well. This last city is seen as the most important center of high school education in the analyzed suburban area. In Stargard there were 17 high schools of all types 
( $46 \%$ of all classes in the suburban area), in which there were 142 school classes ( $48 \%$ of all school classes for this level of schools in the suburban area). Nearly 3,800 pupils attended Stargard high schools ( $51 \%$ of the suburban area), over whom teachers were responsible for education, for whom almost 230 full-time teachers' positions were prepared ( $53 \%$ of all positions for high schools in the suburban area).

High school facilities in the suburban area of Szczecin were located only in urban (Stargard) and urbanrural communes (Goleniów, Gryfino, Police and Pyrzyce). The largest schools were in the Goleniów commune (over 347 pupils per school), while the smallest schools were in the municipality of Pyrzyce (less than 123 pupils per school). In all high schools, the classes had over 20 pupils, reaching extreme values in the Stargard urban community (26.6 pupils in the classroom) and the Pyrzyce municipality (21.8 pupils in the classroom). Although the commune of Pyrzyce was characterized by the least numerous classes, there were the highest number of pupils per one full-time teacher's position (20.3). In the remaining areas, the number of pupils per full-time teacher's position was significantly lower and ranged from 15.4 to 17.5 .

\section{Conclusions}

A synthetic visual presentation of the potential of educational services in the suburban areas of Szczecin is shown in Figure 2. On the basis of this, it should be stated that the greatest potential of educational services is characterized by the Stargard municipality and the municipal-rural communes: Police and Goleniów. The poorest educational level is offered by municipalities located mainly in poorly urbanized areas - rural communes: Banie, and Kobylanka, rural commune Nowe Warpno and rural commune Stargard, in which due to the relatively underdeveloped educational offer, pupils mostly use school facilities located in nearby big cities - Szczecin,

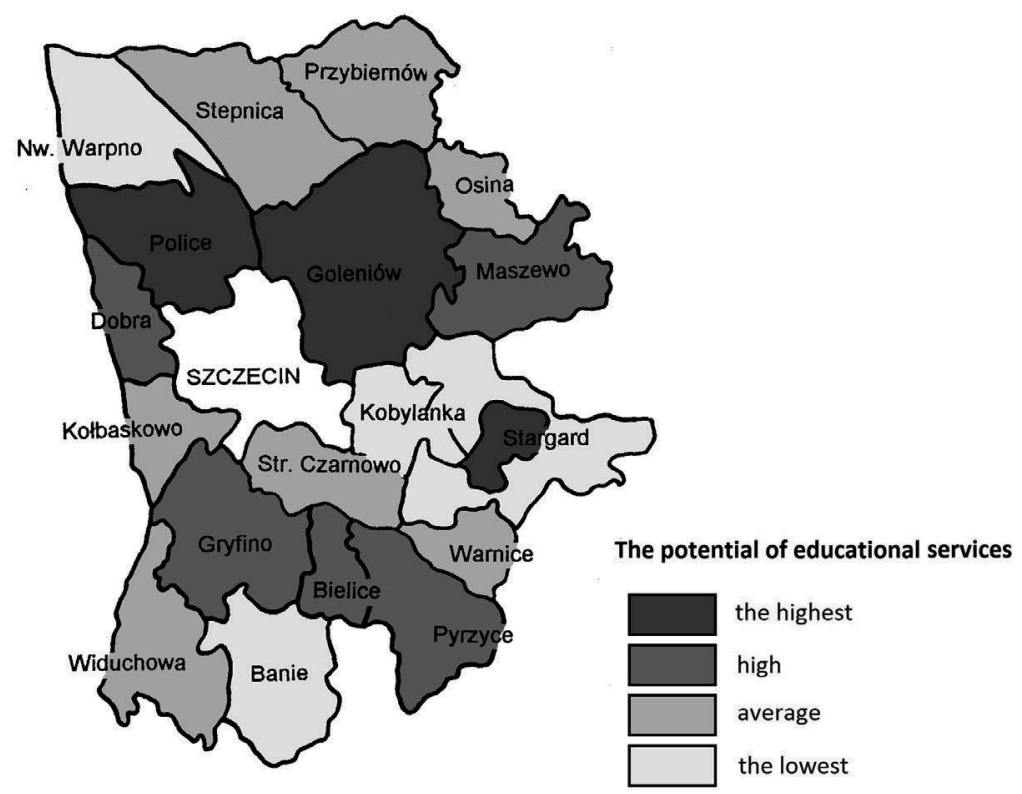

Figure 2. Potential of educational services for the communes of the suburban area of Szczecin in the 2017/2018 school year Source: own study. 
Stargard, Police, Goleniów, Gryfino or Pyrzyce. It should also be noted that the development of the suburban area of Szczecin in the educational sphere, to a large extent, does not keep up with the constantly increasing population of this area. It turns out, however, that neither the intensity of urbanization, nor the urban-rural nature nor the distance from a large or a large city clearly influence the level of universal educational services at the local level, but rather the administrative function of poviats' capital.

\section{Referencences}

Bank Danych Lokalnych GUS (2018). Retrieved from: https://bdl.stat.gov.pl.

Herczyński, J. (2012). Wskaźniki oświatowe. Warszawa: Wydawnictwo ICM.

Konecka-Szydłowska, B. (2006). Wzrost ludnościowy i rozwój budownictwa mieszkaniowego w miastach strefy podmiejskiej Poznania. Biuletyn KPZK PAN, 226, 143-156.

Marcinowicz, D. (2000). Demograficzne źródła wzrostu ludności w strefie podmiejskiej wielkiego miasta (studium Poznania). Biuletyn KPZK PAN, 192, 291-309.

Rozporządzenie Ministra Edukacji Narodowej i Sportu z dnia 26 lutego 2002 r. w sprawie podstawy programowej kształcenia w profilach kształcenia ogólnozawodowego. Dz.U. 2002, no. 50, item. 451.

Rydzewski, T. (2005a). Struktura społeczno-gospodarcza strefy podmiejskiej Szczecina. In: M. Dutkowski, J. Jurek (eds.), Struktura przestrzenna i problemy rozwoju Szczecina w okresie transformacji (pp. 52-60). Szczecin: Oficyna IN PLUS.

Rydzewski, T. (2005b). Przemiany demograficzne w strefie podmiejskiej Szczecina w latach 1978-2003. In: M. Dutkowski, J. Jurek (eds.), Struktura przestrzenna i problemy rozwoju Szczecina w okresie transformacji (pp. 69-80). Szczecin: Oficyna IN PLUS.

Rydzewski, T., Smutek, J. (2016). Wpływ transformacji ustrojowej na przemiany ludnościowe strefy zewnętrznej aglomeracji Szczecina. In: P. Aniśkiewicz, M. Olejniczak (eds.), Interdyscyplinarność w naukach o Ziemi: studia przypadków (pp. 153-165). Szczecin: Wydawnictwo Naukowe Uniwersytetu Szczecińskiego.

The International Standard Classification of Education ISCED (2018). Komisja Europejska, Bruksela. Retrieved from: https:/lec.europa. eu/education/international-standard-classification-of-education-isced_pl.

Ustawa z dnia 14 grudnia 2016 r. - Prawo oświatowe, Dz.U. item. 59.

Ustawa z dnia 14 grudnia 2016 r. - Przepisy wprowadzające ustawę-Prawo oświatowe, Dz.U. item. 60.

Ustawa z dnia 19 sierpnia 2011 r. o zmianie ustawy o systemie oświaty oraz niektórych innych ustaw, Dz.U. no. 205, item. 1206.

Ustawa z dnia 8 stycznia 1999 r. - Przepisy wprowadzające reformę ustroju szkolnego, Dz.U. no. 12, item. 96, z późn. zm.

Województwo zachodniopomorskie - podregiony, powiaty, gminy 2017 (2017). Szczecin: Urząd Statystyczny w Szczecinie.

Cite this article aS: Rydzewski, T. (2018). Educational services in the suburban zone of Szczecin (Poland). European Journal of Service Management, 4 (28/2), 395-401. DOI: 10.18276/ejsm.2018.28/2-47. 